\title{
Representations of Colonial Racism in Monnè, Outrages and Challenges of Ahmadou Kourouma
}

\author{
Ibrahim Boumazzou, Khouloud El Masrar \\ Language and Society Laboratory, Faculty of Letters and Human Sciences, Ibn Tofail University, Kenitra, Morocco
}

Email address:

boumazzou.ibrahim@gmail.com (I. Boumazzou),khouloud.masrar@gmail.com (K. El Masrar)

\section{To cite this article:}

Ibrahim Boumazzou, Khouloud El Masrar. Representations of Colonial Racism in Monnè, Outrages and Challenges of Ahmadou Kourouma. International Journal of Literature and Arts. Vol. 9, No. 1, 2021, pp. 22-24. doi: 10.11648/j.ijla.20210901.14

Received: August 24, 2020; Accepted: November 27, 2020; Published: February 9, 2021

\begin{abstract}
This work explores in a precise way Monnè, outrages and challenges by Ahmadou Kourouma (1990). In it, the novelist reconstructs the colonial history of a region of black Africa (the Mandingo) and makes it an essential base for his poetics. Kourouma traces there in a relatively systematic way the various stages of the installation of the Whites in Soba, from the conquest to the disappointments of independence. He also paints a scenographic picture of the life of Djigui, the king of Soba, from his accession to the throne until his death. He therefore intends to reread this story in order to reflect on the repressive methods adopted by the colonizer at this time. He focuses mainly on the forms of racism of which the novelist speaks in his fiction, notably the question of the "rite of allegiance" and "the ceremony of consumption of the submissive", to cite only these two examples. It shows that the black African community, at the time of colonization, had no value. The latter suffered from various atrocities (repression, violence, marginalization, racism, etc.) [1]. So he is targeting the negative image that Karma's novel talks about. This tends to become a denouncer insofar as the reader is put in a position to take the side of the representatives of this crushed community. By this assigned place, this same reader sees himself led to deem unbearable the fate reserved for the black man who is nevertheless the living and active force of the African continent.
\end{abstract}

Keywords: Monnè, Outrages and Challenges, Ahmadou Kourouma, Colonial Racism

\section{Introduction}

This work is essentially an analysis of some forms of colonial racism in Monnè, outrages and challenges of Ahmadou Kourouma. It is an analysis of the aspects of racism in the book more than it is a theoretical approach to the concept, which came out in 1990 as a great event. On the particular story of this novel, Kourouma confesses in an interview with Jean-Fernand Bédia that he saw that the French continued to speak of their painful period of the occupation and that they had forgotten that They occupied the Africans for fifty or even sixty years. They had been occupying their homes and they had done everything they blamed the Germans for. And it is to respond to this challenge that he wrote Monnè, outrages and challenges [2].

Therefore, the choice of Monnè, the wrath and challenges of Kourouma stems from Kourouma himself and the persistence of his writings. It also finds its justification in the very nature of the historical period that Africa lived during colonization. There is no need to recall that this is a form of violence exerted on peoples considered to be minors and inferior [3]. Kourouma's novel only reflects its after-effects and its cruelties, especially in relation to the inhabitants. Through his intrigue, the author aims not only to transpose the socio-political problems of a people, but also to highlight the nature of the relationships on which colonialism is based, in this case, the superiority of the white race over the black race [4]. Theoretically, it is this "biological difference" [5] which corresponds to what we describe as colonial racism in this work. The following passages can testify to this:

"The negroes are cursed and heartless, true cursed - it is not without reason that God made them black". «(Monnè, p. 82).

"The black is less than the breeze, less than a heron." (p. 171).

"While her husband (the white commander) beat the Negroes to stretch and civilize them, he slept with the Negroes to improve the black race." (P. 117).

To make it clear, we rely on several elements including the question of the extensive exploitation of the natives of Soba (the spatial framework of fiction). Under the yoke of 
colonialism, these were real damned to the land. They were exploited in a cruel and relentless manner. Many passages in the novel show that this exploitation is due particularly to the color of the skin.

The African, the Negro or the Black is a being who is biologically different from the White. It is "less than the breeze, less than a heron» (Monnè). His black skin embodies evil, symbolizes sin and represents the archetype of all lower values. While the white skin is light. The Black is formally forbidden to cohabit with the White. He is part of a false and untrue race. He "is declared impermeable to ethics, corrosive element, destroying everything that approaches it, deforming element, disfiguring everything related to aesthetics or morals, depository of evil forces, unconscious and unrecoverable instrument of blind forces" [6].

Colonial racism therefore includes the overall concept of race. He has a powerful emotional charge [7]. Soba whites feel like they belong to a superior race. When they see the malinkés race before seeing the individuals in front of them.

\section{The "Allegiance Oath"}

In this work, we show that the novel is peppered with racist words, gestures and behaviors. The "allegiance oath" which the Keita (the inhabitants of Soba) were forced after the installation of the "Toubabs" on the hill is a first example.

It is a protectorate treaty that has been concluded with these residents and will not be denounced. Djigui, the king, will not be dethroned. He is only asked to go to camp on Friday, drink the "submissive of submission" and promise that he will renew every Friday, after the great prayer, the oath of allegiance of the Keita to France by a visit to the captain. During these visits, the latter will dictate his wishes. It's up to the narrator to explain:

"The protectorate treaty which was concluded with the Keita will not be denounced. You, Djigui, will not be dethroned. You are only asked to go to camp next Friday after the great prayer drink the disgust of submission and promise that you will renew every Friday, after the great prayer, the oath of allegiance of the Keita to France by a visit to the captain commanding the kebi. During these visits, the captain will dictate his wishes to you. "(P. 46).

"Two things, two feelings: the triumph, the pride, the superiority of the Nazarene Toubab unbeliever victorious by arms who, in an armchair, awaits the allegiance of the negro king believer, defeated, dying» (P. 214).

This rite of allegiance, as evidenced by the passages we have just quoted, is a gesture that condemns the dominated to remain attached to the power and strength of the usurper [8]. If it is a kind of prestige for the racist colonizer, it is, on the contrary, a shame and a bullying for the black-slave. It is an act of submission from the vanquished to the victor, from the Negro to the triumphant White, from the savage to civilized man.

The Whites of Soba, in addition to this ritual, demand colonized inhabitants "offerings, beautiful virgin women, better homes..." (Monnè). Colonial racism feeds on these "benefits". The narrator talks about it:
"Three days later, the captain inspected the tribute brought by those of Soba. Obviously, he seemed happy. The interpreter publicly congratulated the king and the notables and took the opportunity to teach us the name of the operation: the services. The animals, the things, and the food provided constitute services. The men and boys requisitioned were providers." (P. 55)

"Women will make many mulattos, half-whites for Soba which will be a big city" (p. 56)

Among the theoretical references from which we draw inspiration to analyze colonial racism and its forms, we can cite, without being exhaustive: The Man Dominated [9] and Psychology of Colonization [10].

We read there that the colonized is often afflicted with faults and defects which prohibit him to leave his place or to think of changing his social status. He is considered either as a forced laborer in the service of the employer-colonizer, or as a stooge who watches over his well-being. The relationship between the two is based on this "social difference" [11], which difference generates mutual rejection.

Indeed, if the colonizer seeks to completely crush his subject and divert it from his path, the colonized, in turn, tackles annihilating colonial oppression by the unacknowledged questioning of all Western values. In this way the colonizer becomes "suspected, countered, fought in the least of his acts" (A. Memmi).

The colonizer of Monnè, outrages and challenges, as the story clearly shows, does not accept belonging to the world of the black. He is morally and sociologically superior to him for claiming to have links with him. The Keita, for their part, by "defensive racism" react "by refusing all the colonizers en bloc". European racism is matched by African racism. One is induced by the other.

The Soba malinkes seek only the protection of their beliefs, their customs, their ancestors, their dead and their relationships with other tribes [12]. They must see it all before them. It is almost obvious that the two racisms are not of the same nature because "the personalities do not have the same structures". The African also knows that "the primary elements that exist in his psyche are different from those of the colonizer." But that doesn't stop him from blaming him for a few flaws. All the colonized is looking for is a "new form of security." "Overcompensating for a complex inferiority" (O. Mannoni) does not interest him. It is in this context that colonial racism, the subject of our contribution, should be replaced.

The rite of allegiance that we analyze in this contribution is mechanically linked with another ritual whose reference is very recurrent in the novel by Kourouma. This is, of course, "the essential consummation ceremony for the submissive" (Monnè). This is a second example of the manifestations of colonial racism we are talking about here.

\section{The "Disgusted Submission"}

The "disgusted submission" is an African warrior tradition. It is well described in Kourouma's novel. By its application to Soba, the French colonizer asked Djigui for his submission 
while bringing him in exchange his "protectorate". Soba is obliged to accept it because there are no other issues for this tiny kingdom. Here's what the narrator says:

"Since the defeat, Djigui had engaged in long prayers; they were half answered. He feared and prayed that he would not be required to convert to Nazarism. This curse did not appear. He also prayed that he would not be asked to drink the disgust, to perjure himself. This dishonor was not spared him" (P. 46).

The ceremony took place at the headquarters of whites. It immediately follows the great Friday prayer and this accentuates its humiliating and outrageous character. The Whites are Christians and the Keita fear forced conversions to the religion of the colonizers. This is why the sages of Soba consider it a fatality, as evidenced by these passages from the novel:

"Allah and the souls of the dead asked us to submit to those who had defeated us with arms, as long as we were not asked to change our religion," said the king of Soba. (P. 47).

"I launched myself, with all my team, in a mad ride towards the Kebi narrowly avoiding those who deviated from the crowd assembled on the sides of the road. Friday's visit to the white "Nazaras" which was to be one of the most striking rites of the negro of Djigui Keita, king of Soba, had just found its ceremonial."(P. 49-50)

The "submission" scene seals the Keita's ties to the Whites. The colonizer is not ready to abandon it. It is essential to him. Djigui, this old illiterate, would probably have refused to sign a virtual and distant "protectorate treaty" because very different from his realities. But, the colonists knew well how to place it in a space which it controls better. He is faced with a concrete rite. By going to celebrate the "submission" ceremony, Djigui understood better the scope of his act.

In Kourouma's novel, the "submission ceremony" suggests a double aspect. It is considered an outrage, a humiliation [13], but at the same time, and, of course, on an essentially symbolic level, a challenge, or, at least, an affirmation of identity and continuity. This ritual manifests both Soba's defeat and her resistance since she adapts to the situation and succeeds in overcoming fate. This ceremony is repeated several times by the narrator. It even punctuates Kourouma's novel. We meet it, in fact, in the fourth, fifth and sixth chapter. It is for this reason that we give it an important place in our work.

\section{Conclusion}

Before closing, it must therefore be pointed out that the two examples that we have just mentioned ("the rite of allegiance" and " the submission ceremony") and others such as "benefits", forced labor, construction of the road, the promise of the railway and "the seasons of bitterness", show that the colonial past of black Africa is stained with many humiliations and injustices [14]. Admittedly, Monnè's actions, outrages and challenges of Ahmadou Kourouma are now in a bygone era. But, they extend to the present day. The atrocities witnessed by the writer continue to resound in the present. Racism has not disappeared [15]. It is still rampant.

\section{References}

[1] Sartre, J. P. Situations V, Colonialism and neo-colonialism. Paris. Gallimard. 1964.

[2] Kourouma, A. Monnè, outrages and challenges. Paris. Seuil. 1990.

[3] Rousseau, J. J. Discourse on the origin and foundations of inequality among person. Paris. Gallimard. 1969.

[4] Ki-Zerbo, J. The fifty africas. Paris. Seuil. 1979.

[5] Memmi, A. Portrait of the colonized preceded by portrait of the colonizer. Paris. Payot. 1973.

[6] Fanon, F. The damned of the earth. Paris. The discovery. 2002.

[7] Senghor, L. S. Anthology of the new French-speaking poetry and Algasian language. Paris. University Press of France. 1948 .

[8] Ziegler, J. African power. Paris. Seuil. 1979.

[9] Memmi, A. The dominated person. Paris. Gallimard. 1968.

[10] Mannoni, O. Colonization psychology. Paris. Seuil. 1950.

[11] Césaire, A. Discourse on colonialism. Paris. African presence. 1955.

[12] Mauss, M. Sociology and anthropology. Sketch of a general theory of magic. Paris. University Press. 2009.

[13] Joppa, F. A. The commitment of French-speaking black Africans. Canada. Naaman Editions. 1982.

[14] N'Dongo, S. Cooperation and neo-colonialism. Paris. Maspero. 1976.

[15] Yvan, G. (2010). Albert Memmi, A postcolonial look. Postcolonial ruptures. Achille Mbembe editions. The discovery, pp 88-95. 